Abstracta Iranica

Revue bibliographique pour le domaine irano-aryen

Volume 32-33 | 2013

Comptes rendus des publications de 2009-2010

\title{
Stephen F. Dale. The Muslim Empires of the Ottomans, Safavids, and Mughals
}

\section{Aurélie Chabrier}

\section{OpenEdition}

1 Journals

\section{Édition électronique}

URL : http://journals.openedition.org/abstractairanica/40658

DOI : 10.4000/abstractairanica.40658

ISSN : 1961-960X

Éditeur :

CNRS (UMR 7528 Mondes iraniens et indiens), Éditions de l'IFRI

\section{Édition imprimée}

Date de publication : 1 décembre 2013

ISSN : 0240-8910

\section{Référence électronique}

Aurélie Chabrier, "Stephen F. Dale. The Muslim Empires of the Ottomans, Safavids, and Mughals », Abstracta Iranica [En ligne], Volume 32-33 | 2013, document 237, mis en ligne le 01 juillet 2016, consulté le 27 septembre 2020. URL : http://journals.openedition.org/abstractairanica/40658 ; DOI : https://doi.org/10.4000/abstractairanica.40658

Ce document a été généré automatiquement le 27 septembre 2020.

Tous droits réservés 


\title{
Stephen F. Dale. The Muslim Empires of the Ottomans, Safavids, and Mughals
}

\author{
Aurélie Chabrier
}

\section{RÉFÉRENCE}

Stephen F. Dale. The Muslim Empires of the Ottomans, Safavids, and Mughals. Cambridge, Cambridge University Press, 2010, 347 p.

Dans cette histoire comparative des Empires ottoman, safavide et moghol depuis leur émergence (à partir du XV ${ }^{\mathrm{e}} \mathrm{s}$.) jusqu'à leur disparition (entre le XVIII ${ }^{\mathrm{e}}$ et le $\mathrm{XX}^{\mathrm{e}} \mathrm{s}$.), l'A. étudie ce qui constitue à maint égards un «âge d'Or » de la civilisation musulmane. Il s'intéresse ainsi aux divers aspects qui ont conduit ces empires musulmans au faîte de leur puissance à l'époque moderne : force militaire ("The rise of Muslim empires »), bien sûr, mais aussi économie ("The economies around $1600 »)$, culture impériale et rayonnement artistique ("The imperial cultures»). Un soin particulier est accordé à l'art, à la poésie et à l'architecture («Golden ages: profanes and sacred empires » / "Imperial culture in the golden age »), qui sont autant de symboles de la sophistication de leurs sociétés. Un tableau complexe du monde musulman se dessine ; irrigué par les apports des cultures turco-mongole, timouride et persane. Les conditions de son déclin, avec la disparition successive de ces trois empires, malgré des tentatives de réformes ("Quest for a phoenix »), sont mises en exergue dans la conclusion de l'ouvrage. Enfin, si l'A. se préoccupe constamment de la spécificité de chaque empire, il prend aussi soin de mettre en avant leurs convergences; leur unité sous-jacente, répondant ainsi parfaitement à sa problématique de départ. 


\section{AUTEURS}

AURÉLIE CHABRIER

Paris 